\title{
Kontribusi Kualitas Layanan Ritel di Toko Basmalah Kasiyan Kecamatan Puger dan Pengaruhnya Terhadap Keputusan Pembelian Konsumen
}

\author{
Tri Palupi Robustin \\ STIE Widya Gama Lumajang \\ Email: tripalupirobustin@gmail.com
}

\begin{abstract}
This study aims to determine the partial effect of physical aspects, reliability, personal interaction, problem solving, policies on purchasing decisions at Kasiyan Basmalah Store and to determine the simultaneous effect of physical aspects, reliability, personal interaction, problem solving, policies on purchasing decisions at Kasiyan Basmalah Store. The population of this study are consumers who buy at the Basmallah Kasiyan Shop, Puger District. The sampling technique used was non-probability sampling, namely Accidental sampling. The analysis used in this study is a multivariate analysis, namely multiple linear regression analysis. The results prove that the physical aspects, reliability, personal interaction, and problem solving have a significant effect on product purchasing decisions and there is no policy influence on purchasing decisions at Kasiyan Basmalah Store.

Keywords: purchasing decisions, physical aspects, reliability, personal interaction
\end{abstract}

\section{Pendahuluan}

Perusahaan di era perdagangan bebas saat ini menghadapi persaingan yang semakin ketat. Meningkatnya intensitas persaingan dan jumlah pesaing menuntut perusahaan untuk selalu memperhatikan kebutuhan dan keinginan konsumen serta berusaha memenuhi harapannya. Dengan cara perusahaan memberikan kualitas layanan yang lebih baik kepada konsumen dari pada yang dilakukan oleh pesaing, dengan demikian, hanya perusahaan yang menjual produk/jasa yang berkualitas yang dapat bersaing dan dapat menguasai pasar. Kualitas layanan memang menjadi salah satu faktor terpenting bagi sebuah perusahaan dimana untuk memuaskan konsumen atau pelanggan perusahaan harus berlomba-lomba menciptakan suatu produk/jasa yang dinilai memiliki kualitas yang baik di bandingkan dengan perusahaan lain.

Nilai yang diberikan pelanggan sangat kuat didasari oleh faktor kualitas jasa. Di mana kualitas produk (jasa) adalah sejauh mana produk (jasa) memenuhi 
spesifikasi-spesifikasinya. Kualitas menurut ISO 9000 adalah: "degree to which a set of inherent characteristics fulfils implied or obligatory" (derajat yang dicapai oleh karakteristik yang inheren dalam memenuhi persyaratan). Persyaratan dalam hal ini adalah: "need or expectation that is stated, generally implied or obligatory" (yaitu, kebutuhan atau harapan yang dinyatakan, biasanya tersirat atau wajib). Jadi, kualitas sebagaimana yang diinterpretasikan ISO 9000 merupakan perpaduan antara sifat dan karakteristik yang menentukan sejauh mana keluaran dapat memenuhi persyaratan kebutuhan pelanggan. Pelanggan yang menentukan dan menilai sampai seberapa jauh sifat dan karakteristik itu memenuhi kebutuhannya. Kualitas merupakan suatu kondisi dinamis yang berpengaruh dengan produk, jasa, manusia, proses dan lingkungan yang memenuhi atau melebihi harapan (Tjiptono, 2001). Sehingga definisi kualitas pelayanan dapat diartikan sebagai upaya pemenuhan kebutuhan dan keinginan konsumen serta ketepatan penyampaiannya dalam mengimbangi harapan konsumen (Tjiptono, 2007).

Menurut Kotler (2010:211) proses pembelian yg spesifik terdiri dari urutan kejadian sebagai berikut: pengenalan masalah, pencarian informasi, evaluasi alternatif, keputusan pembelian, dan perilaku pasca pembelian. Tugas pemasar yaitu memahami perilaku pembeli pada tiap tahap dan pengaruh apa yg bekerja dalam tahap-tahap tersebut. Untuk melakukan pembelian, konsumen tidak terlepas dari karakteristik produk baik mengenai penampilan, gaya, mutu dan harga dari produk tersebut.

Indonesia naik tiga peringkat ke posisi lima besar di antara 200 negara berkembang dalam Global Retail Development Index 2019 versi AT Kearney yang dilansir Januari 2020. Penjualan ritel Indonesia sepanjang tahun lalu mencapai angka 396 miliar dollar AS, mengalahkan penjualan ritel Malaysia dengan 110 miliar dollar AS. Salah satu toko ritel yang sedang tumbuh adalah Toko Basmalah dari Koperasi Pondok Pesantren Sidogiri yang berdiri sejak 1961. Toko Basmalah berkembang dan berpusat di Jawa Timur, tercatat tahun 2018 sekitar 200 outlet. Hal ini tentu saja akan terus bertambah demi kemaslahatan. Selain perbandingan harga yang lebih murah, Mereka mampu memberdayakan santri dan masyarakat ikut andil dalam kemajuan toko. 
(https://www.kaskus.co.id/thread/5dafe86ec8393a188845363d/toko-basmalahpenantang-baru-supermarket-di-indonesia/)

Berdasarkan latar belakang masalah, perumusan masalah yang diajukan maka tujuan penelitian ini adalah :

1. Untuk mengetahui pengaruh aspek fisik (physical aspect) terhadap keputusan pembelian di Toko Basmalah Kasiyan?

2. Untuk mengetahui pengaruh reliabilitas (reliability) terhadap keputusan pembelian di Toko Basmalah Kasiyan?

3. Untuk mengetahui pengaruh interaksi personal (personal interaction) terhadap keputusan pembelian di Toko Basmalah Kasiyan?

4. Untuk mengetahui pengaruh pemecahan masalah (problem solving) terhadap keputusan pembelian di Toko Basmalah Kasiyan?

5. Untuk mengetahui pengaruh kebijakan (policy) terhadap keputusan pembelian di Toko Basmalah Kasiyan?

6. Untuk mengetahui pengaruh secara simultan aspek fisik (physical aspect), reliabilitas (reliability), interaksi personal (personal interaction), pemecahan masalah (problem solving), kebijakan (policy) terhadap keputusan pembelian di Toko Basmalah Kasiyan?

\section{Tinjauan Pustaka}

\subsection{Kualitas Layanan}

Kualitas merupakan suatu kondisi dinamis yang berpengaruh dengan produk, jasa, manusia, proses dan lingkungan yang memenuhi atau melebihi harapan (Tjiptono, 2001). Sehingga definisi kualitas pelayanan dapat diartikan sebagai upaya pemenuhan kebutuhan dan keinginan konsumen serta ketepatan penyampaiannya dalam mengimbangi harapan konsumen (Tjiptono, 2007). Menurut Kotler (2002:83) definisi pelayanan adalah setiap tindakan atau kegiatan yang dapat ditawarkan oleh suatu pihak kepada pihak lain, yang pada dasarnya tidak berwujud dan tidak mengakibatkan kepemilikan apapun. Produksinya dapat dikaitkan atau tidak dikaitkan pada satu produk fisik. Pelayanan merupakan perilaku produsen dalam rangka memenuhi kebutuhan dan keinginan konsumen 
demi tercapainya kepuasan pada konsumen itu sendiri. Kotler juga mengatakan bahwa perilaku tersebut dapat terjadi pada saat, sebelum dan sesudah terjadinya transaksi. Pada umumnya pelayanan yang bertaraf tinggi akan menghasilkan kepuasan yang tinggi serta pembelian ulang yang lebih sering. Kata kualitas mengandung banyak definisi dan makna, orang yang berbeda akan mengartikannya secara berlainan tetapi dari beberapa definisi yang dapat kita jumpai memiliki beberapa kesamaan walaupun hanya cara penyampaiannya saja biasanya terdapat pada elemen sebagai berikut:

1. Kualitas meliputi usaha memenuhi atau melebihkan harapan pelanggan.

2. Kualitas mencakup produk, jasa, manusia, proses dan lingkungan

3. Kualitas merupakan kondisi yang selalu berubah.

Hingga saat ini terdapat dua model generik paling populer untuk mengukur kualitas layanan offline. Total Perceived Quality Model (TPQM) dan SERVQUAL. TPQM yang dikembangkan oleh Gronroos $(1984,1990)$ menguraikan kualitas layanan ke dalam dua dimensi pokok. Pertama, technical quality (outcome dimension) berkaitan dengan kualitas output layanan yang dipersepsikan pelanggan. Komponen ini dapat dijabarkan lagi menjadi tiga tipe: search quality (unsur layanan yang dapat dievaluasi sebelum dibeli, misalnya harga), experience quality (hanya bisa dievaluasi setelah dikonsumsi, contohnya ketapatan waktu, kecepatan layanan, dan kerapian hasil), serta credence quality (sukar dievaluasi pelanggan sekalipun layanan telah dikonsumsi, misalnya kualitas operasi bedah otak).

Dimensi kedua, functional quality (process-related dimension) berkaitan dengan kualitas cara penyampaian layanan atau menyangkut proses transfer kualitas teknis, output atau hasil akhir kepada pelanggan. Contohnya meliputi aksesibiltas mesin ATM, restoran atau konsultan bisnis, penampilan dan perilaku pramusaji, teller bank, pemandu wisata, supir bis, atau pramugari; serta cara setiap karyawan menjalankan tugas mereka serta apa saja yang mereka ucapkan. Selain itu, functional quality juga dipengaruhi kehadiran pelanggan lain yang pada waktu bersamaan sama-sama mengkonsumsi layanan. Mereka bisa menyebabkan antrian panjang atau mengganggu pelanggan tertentu; namun di lain pihak, mereka bisa 
pula mempengaruhi terciptanya suasana interaksi pembeli-penjual yang menyenangkan. Bila dibandingkan dengan technical quality, dimensi functional quality umumnya dipersepsikan secara subyektif dan tidak bisa dievaluasi seobyektif technical quality.

Sementara itu, model SERVQUAL dirumuskan Parasuraman, Zeithaml, dan Berry $(1985,1988,1990,1991,1993,1994)$ berdasarkan serangkaian penelitian mereka terhadap enam sektor jasa : reparasi peralatan rumah tangga, kartu kredit, asuransi, sambungan telepon interlokal, perbankan ritel, dan pialang sekuritas. Model ini berfokus pada 5 gap yang berpengaruh terhadap kualitas layanan. Gap pertama terjadi antara harapan pelanggan terhadap persepsi manajemen (knowledge gap). Contohnya, pengelola jasa catering mungkin saja mengira bahwa para pelanggannya lebih mengutamakan ketepatan waktu pengantaran makanan, padahal mereka justru lebih mementingkan variasi menu yang disajikan. Gap kedua terjadi antara persepsi manajemen terhadap harapan konsumen dan spesifikasi kualitas layanan (standards gap). Contohnya, manajemen sebuah bank meminta para stafnya agar melayani nasabah dengan cepat tanpa merinci standar waktu pelayanan yang bisa dikategorikan cepat.

Gap ketiga terjadi antara spesifikasi kualitas layanan dan penyampaian layanan (delivery gap). Sebagai contoh, para perawat sebuah rumah sakit diwajibkan meluangkan waktunya untuk mendengarkan keluhan/masalah pasien, tetapi disaat bersamaan mereka juga diharuskan melayani setiap pasien dengan cepat. Gap keempat menyangkut perbedaan antara penyampaian layanan dan komunikasi eksternal (communication gap). Contohnya, wisatawan akan sangat kecewa apabila mereka mendapati bahwa objek wisata yang dikunjungi ternyata tidak sebagus yang digambarkan di brosur atau website yang mereka lihat. Gap kelima merupakan gap antara perceived service dan expected service (service gap). Sebagai contoh, seorang dokter mungkin ingin selalu mengunjungi pasiennya demi menunjukkan perhatiannya, namun itu bisa dipersepsikan keliru oleh seorang pasien dan diinterpretasikan sebagai indikasi bahwa ada masalah serius berkenaan dengan penyakit yang dideritanya. 
Pengukuran kualitas jasa dalam model SERVQUAL didasarkan pada skala multi-item yang dirancang untuk mengukur expected service dan perceived service, serta gap diantara keduanya dalam dimensi-dimensi utama kualitas layanan. Pada penelitian awalnya, Parasuraman, et al., (1985) mengidentifikasi sepuluh dimensi pokok, yakni reliabilitas, daya tanggap, kompetensi, akses, kesopanan, komunikasi, kredibilitas, keamanan, kemampuan memahami pelanggan, dan bukti fisik.

Namun, pada penelitian berikutnya, ketiga pakar ini merangkum 10 dimensi tersebut ke dalam 5 dimensi pokok. Kompetensi, kesopanan, kredibilitas, dan keamanan disatukan menjadi jaminan (assurance), sedangkan akses, komunikasi, dan kemampuan memahami pelanggan dikategorikan sebagai empati. Kelima dimensi tersebut meliputi: (1) reliabilitas, yaitu kemampuan memberikan layanan yang dijanjikan dengan segera, akurat, dan memuaskan; (2) daya tanggap, yaitu keinginan para staf untuk membantu para pelanggan dan memberikan layanan dengan tanggap; (3) jaminan, mencakup pengetahuan, kompetensi, kesopanan, dan sifat dapat dipercaya yang dimiliki para staf, serta bebas dari bahaya, risiko maupun keragu-raguan; (4) empati, meliputi kemudahan dalam menjalin relasi, komunikasi yang baik, perhatian pribadi dan pemahaman atas kebutuhan individual para pelanggan; dan (5) bukti fisik, meliputi fasilitas fisik, perlengkapan, pegawai, dan sarana komunikasi.

Sejauh ini model SERVQUAL sudah diterapkan di beraneka ragam konteks, baik untuk sektor komersial, industrial, maupun nirlaba. Contohnya meliputi: jasa dokter, hotel, tur wisata, reparasi mobil, sekolah bisnis, universitas, konsultasi manajemen dan akuntansi, rumah sakit, bank, jasa ritel pakaian, instansi pemerintah, jasa konstruksi, broker saham, toserba, industri perangkat lunak komputer, jasa telekomunikasi, jasa kartu kredit, restoran siap saji, dry cleaning, dan sebagainya.

\subsection{Retail Service Quality}

Model SERVQUAL dalam pemasaran jasa banyak yang mengkritik penggunaaan model tersebut pada berbagai bidang industri jasa. Dabholkar et al., (1996) mengkritik bahwa model SERVQUAL tidak mampu menjelaskan secara akurat persepsi pelanggan terhadap kualitas jasa/layanan toko ritel, yaitu toko yang 
menjual berbagai macam barang dan jasa (seperti pasar swalayan, toserba, dan specialty stores). Contohnya adalah sejumlah dimensi yang relevan untuk konteks toko ritel justru tidak tercakup dalam model SERVQUAL, diantaranya pengalaman pelanggan dalam mencari produk yang mereka butuhkan diantara rak-rak pajangan, interaksi dengan staf toko sewaktu berbelanja di toko, dan pengalaman berkaitan dengan pengembalian produk yang tidak sesuai dengan harapan sehingga dimensi kualitas jasa khusus untuk konteks toko ritel dibutuhkan.

Dimensi kualitas jasa ritel menurut Dabholkar et al., (1996) antara lain:

1. Aspek fisik (physical aspects), meliputi penampilan fisik dan kenyamanan yang di tawarkan kepada pelanggan berkaitan dengan layout fasilitas fisik (misalnya, memudahkan pelanggan untuk bergerak di dalam toko dan mencari barang yang dibutuhkan).

2. Reliabilitas (reliability), yang pada prinsipnya sama dengan dimensi reliabilitas pada model SERVQUAL, hanya saja di sini reliabilitas dipilah ke dalam 2 subdimensi, yaitu memenuhi janji (keeping promises) dan memberikan layanan dengan tepat (doing it right).

3. Interaksi personal (personal interaction), mengacu pada kemampuan karyawan jasa dalam menumbuhkan kepercayaan pelanggan dan sikap sopan/suka membantu. Pada prinsipnya, dimensi ini berkaitan dengan cara karyawan memperlakukan para pelanggan.

4. Pemecahan masalah (problem solving), berkaitan dengan penanganan retur, penukaran, dan complain.

5. Kebijakan (policy), mencakup aspek-aspek kualitas jasa yang secara langsung dipengaruhi kebijakan toko, seperti jam operasi, fasilitas parkir, dan pemakaian kartu kredit.

\subsection{Keputusan Pembelian}

Keputusan pembelian adalah preferensi konsumen atau merek-merek yang ada di dalam kumpulan pilihan dan niat konsumen untuk membeli merek yang paling disukai (Kotler dan Keller, 2008:188). Menurut Kotler dan Keller (2008:184) ada 5 model tahap keputusan pembelian : pengenalan masalah, pencarian informasi, evaluasi alternatif, keputusan pembelian dan perilaku pascapembelian. 
1. Pengenalan masalah

Proses pembelian dimulai ketika pembeli menyadari suatu masalah atau kebutuhan yang dipicu oleh rangsangan internal atau eksternal.

2. Pencarian informasi

Konsumen sering mencari jumlah informasi yang terbatas. Dapat membedakan antara dua tingkat keterlibatan dengan pencarian. Keadaan pencarian yang lebih rendah disebut perhatian tajam. Pada tingkat ini seseorang hanya menjadi lebih reseptif terhadap informasi tentang sebuah produk. Pada tingkat berikutnya, seseorang dapat memasuki pencarian informasi aktif.

3. Evaluasi alternatif

Ada beberapa proses, dan sebagian besar model terbaru melihat konsumen membentuk sebagian besar penilaian secara sadar dan rasional. Pertama, konsumen berusaha memuaskan sebuah kebutuhan. Kedua, konsumen mencari manfaat tertentu dari solusi atribut. Ketiga, konsumen melihat masing-masing produk sebagai sekelompok atribut dengan berbagai kemampuan untuk menghantarkan manfaat yang diperlukan untuk memuaskan kebutuhan ini.

4. Keputusan pembelian

Dalam tahap evaluasi, konsumen membentuk preferensi antarmerek dalam kumpulan pilihan. Konsumen mungkin juga membentuk maksud untuk membeli merek yang paling disukai.

5. Perilaku pascapembelian

Setelah pembelian, konsumen mungkin mengalami konflik dikarenakan melihat fitur mengkhawatirkan tertentu mendengar hal-hal menyenangkan tentang merek lain dan waspada terhadap informasi yang mendukung keputusannya. Komunikasi pemasaran seharusnya memasok keyakinan dan evaluasi yang memperkuat pilihan konsumen dan membantunya merasa nyaman tentang merek tersebut.

\section{Metode Penelitian}

\subsection{Jenis Penelitian}


Penelitian ini termasuk jenis penelitian survei (survey research) yaitu penelitian yang tidak melakukan perubahan atau tidak ada perlakuan khusus terhadap variabel-variabel yang diteliti (non experimental). Tujuan penelitian ini bersifat eksplanatori (explanatory research) dan prediksi dimana penelitian eksplanatori merupakan jenis penelitian yang menjelaskan hubungan kausal antara satu variabel dengan variabel lainnya melalui pengujian hipotesis. Berdasarkan sifatnya, penelitian ini bersifat eksploratif karena pengujian lebih lanjut atas suatu penelitian diperlukan maka penelitian tersebut bersifat eksploratif.

\subsection{Populasi dan Teknik Pengambilan Sampel}

Populasi penelitian ini adalah konsumen yang membeli di Toko Basmalah Kasiyan Kecamatan Puger. Teknik pengambilan sampel yang digunakan adalah non probability sampling yaitu Accidental sampling. Accidental sampling menurut Sugiyono (2009:85) adalah teknik pengambilan sampel berdasarkan kebetulan, yaitu konsumen yang secara kebetulan atau insidental bertemu dengan peneliti dapat digunakan sebagai sampel, bila dipandang orang yang kebetulan ditemui itu cocok sebagai sumber data. Metode penentuan ukuran sampel yang digunakan adalah metode yang dikembangkan oleh Roscoe dalam bukunya Research Methods For Business (1982:253) seperti yang dikutip dalam (Sugiyono, 2009:129), yaitu bila penelitian akan melakukan analisis dengan multivariat maka jumlah anggota sampel minimal 10 (sepuluh) kali dari jumlah variabel yang diteliti, termasuk di dalamnya adalah jumlah variabel independen dan dependen. Analisis yang digunakan dalam penelitian ini merupakan analisis multivariat yaitu analisis regresi linier berganda yang keseluruhan terdiri dari 6 (enam) variabel, sehingga ukuran sampel yang diambil minimal $=10 \times 6$ variabel $=60$ anggota sampel .

\subsection{Teknik Pengumpulan Data}

Teknik pengumpulan data adalah dengan menggunakan kuesioner yang diberikan kepada konsumen yang membeli di Toko Basmalah Kasiyan Kecamatan Puger. Teknik pengukuran yang digunakan dalam penelitian ini adalah skala likert. Skala lilkert digunakan untuk mengukur sikap, pendapat dan persepsi seseorang atau sekelompok tentang kejadian atau gejala sosial (Riduwan, 2008:20). Rentang skala yang digunakan untuk mengukur derajat sangat tidak setuju atau sangat setuju 
untuk setiap indikator variabel dalam penelitian ini adalah 1 (satu) sampai 5 (lima) yaitu dengan tingkat pembobotan sebagai berikut :
a. Sangat Setuju
: skor 5
b. Setuju
: skor 4
c. Netral
: skor 3
d. Tidak Setuju
: skor 2
e. Sangat Tidak Setuju
: skor 1

\subsection{Model Penelitian}

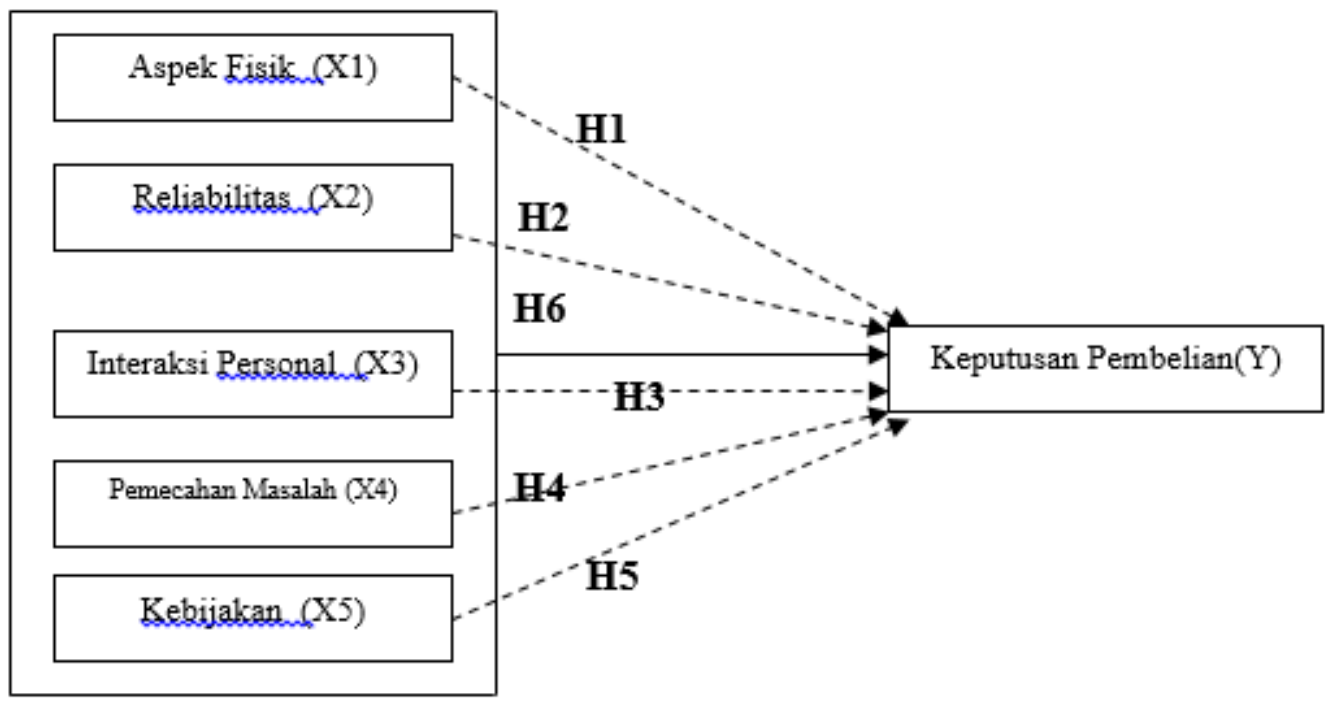

Sumber: data diolah 2020

\section{Gambar 1. Model Penelitian}

Keterangan:

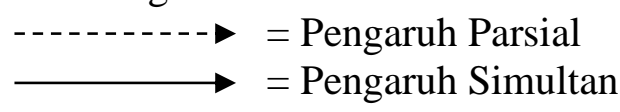

\subsection{Teknik Analisis Data}

\subsubsection{Pengujian Instrumen Penelitian}

\subsubsection{Pengujian Validitas}

Uji validitas diperlukan untuk memastikan bahwa pertanyaan yang dibuat dapat mencerminkan dimensi yang akan diukur. Menurut Siregar (2015:75),validitas atau kesahihan menunjukkan sejauh mana suatu alat ukur mampu mengukur apa yang ingin diukur. Syarat minimum untuk suatu data 
kuantitatif dianggap memenuhi syarat validitas apabila $r$ minimal bernilai 0,3 atau $r$ hitung > r tabel. Jadi jika korelasi antara butir dengan skor total kurang dari 0,3 atau $\mathrm{r}$ hitung < $\mathrm{r}$ tabel, maka butir-butir dalam instrumen tersebut dinyatakan tidak valid dan sebaliknya.

\subsubsection{Pengujian Reliabilitas}

Reliabilitas atau keandalan dilakukan untuk mengetahui sampai sejauh mana kuesioner yang diajukan dapat memberikan hasil yang tidak berbeda (Sugiyono, 2008:137).

Pengujian terhadap reliabilitas dan penelitian dapat dilakukan dengan menghitung besarnya Cronbach Alpha ( $\alpha$ ). Koefisien Alpha Cronbach menunjukkan sejauh mana kekonsistenan responden dalam menjawab instrumen yang dinilai. Menurut Basuki dan Prawoto (2016:79), uji realibilitas dilakukan dengan uji Alpha Cronbach, yaitu:

1. Jika alpha $>0,90$ maka reliabilitas sempurna

2. Jika alpha antara 0,70-0,90 maka reliabilitas tinggi

3. Jika alpha $0,50-0,70$ maka reliabilitas moderat

4. Jika alpha $<0,50$ maka reliabilitas rendah

\subsubsection{Pengujian Asumsi Dasar Regresi Linier Berganda}

\subsubsection{Pengujian Normalitas Data}

Menurut Basuki dan Prawoto (2016:57), uji normalitas berguna untuk menentukan data yang telah dikumpulkan berdistribusi normal atau diambil dari populasi normal. Metode klasik dalam pengujian normalitas suatu data tidak terlalu begitu rumit. Berdasarkan pengalaman empiris beberapa pakar statistik, data yang banyaknya lebih dari 30 angka ( $\mathrm{n}>30$ ), maka sudah dapat diasumsikan berdistribusi normal. Biasa dikatakan sebagai sampel besar. Salah satu cara untuk melihat normalitas adalah secara visual yaitu melalui Normal P-P Plot, ketentuannya adalah jika titik-titik masih berada di sekitar garis diagonal maka dapat dikatakan bahwa residual menyebar normal.

\subsubsection{Pengujian Multikolinieritas}

Menurut Basuki dan Prawoto (2016:61), multikolinieritas atau kolinearitas ganda (multicollinearity) adalah adanya hubungan linear antara peubah bebas X 
dalam model regresi ganda. Multikolinieritas juga berarti antara variabel bebas yang satu dengan variabel bebas yang lain saling berkorelasi linier. Berarti multikolinieritas dapat dikatakan sebgai suatu keadaan dimana variabel-variabel independen dalam suatu persamaan mempunyai hubungan yang kuat. Biasanya korelasinya mendekati sempurna (koefisien korelasinya tinggi atau bahkan satu). Pendeteksian terhadap multikolineaitas akan dilakukan dengan melihat nilai VIF (Variance Inflantion Factor). Kriteria pengujiannya yaitu apabila nilai VIF $<10$ maka tidak terdapat multikolinearitas diantara variabel independen dan sebaliknya jika nilai VIF > 10 berarti terdapat multikolinieritas, (Basuki dan Prawoto, 2016:62).

\subsubsection{Pengujian Heteroskedastisitas}

Heteroskedastisitas adalah adanya ketidaksamaan varian dari residual untuk semua pengamatan pada model regresi (Basuki dan Prawoto 2016:63). Salah satu cara untuk mendekati heteroskedastisitas adalah dengan melihat grafik scatter plot antara nilai prediksi variabel terikat (ZPRED) dengan residualnya (SRESID). Jika ada titik-titik membentuk pola tertentu yang teratur seperti bergelombang, melebar, kemudian menyempit maka telah terjadi heteroskedastisitas. Jika titiktitik menyebar di atas dan di bawah angka 0 pada sumbu Y tanpa membentuk pola tertentu maka tidak terjadi heteroskedastisitas.

\subsubsection{Analisis Regresi Linier Berganda}

Menurut Siregar (2015:405), regresi berganda merupakan pengembangan dari regresi linier sederhana, yaitu suatu alat analisis yang bertujuan untuk mengetahui pengaruh satu atau lebih variable bebas (independent) terhadap satu variabel tidak bebas (dependent).

Formulasi umum untuk regresi berganda adalah sebagai berikut:

$Y=a+b_{1} X_{1}+b_{2} X_{2}+\ldots+b_{n} X_{n}+e$

Dimana :

$\mathrm{Y}=$ variabel dependen

$\mathrm{X}=$ variabel independen

$\mathrm{a}=$ konstanta

$\mathrm{b}=$ koefisien regresi variabel independen 
$\mathrm{e}=$ Residual/error

Fungsi persamaan regresi selain untuk memprediksi nilai Dependent Variable (Y), juga dapat digunakan untuk mengetahui arah dan besarnya pengaruh Independent Variable (X) terhadap Dependent Variable (Y).

\subsubsection{Pengujian Hipotesis}

\section{a. Uji t (Uji Parsial)}

Menurut Algifari (2015:77), uji koefisien regresi (uji t) bertujuan untuk menguji hipotesis tentang pengaruh variabel independen terhadap variabel dependen. Widarjono (2015:22) menyatakan bahwa uji t berfungsi untuk memberikan bukti terhadap variabel independen secara parsial memiliki pengaruh terhadap variabel dependen. Peneliti mengajukan dua hipotesis yaitu hipotetsis nol Ho dan hipotesis alternatif Ha. Hipotesis nol disebutkan dengan anggapan benar yang kemudian akan dibuktikan salah dengan sampel yang ada. Sedangkan hipotesis alternatif disebutkan harus memiliki kebenaran ketika hipotesis nol dibuktikan salah.

Menentukan level signifikasi $\alpha=5 \%$

1) Menentukan kriteria pengujian:

Apabila $-\mathrm{t}$ tabel $>\mathrm{t}$ hitung $>\mathrm{t}$ tabel,maka Ho ditolak dan Ha diterima

Apabila $-\mathrm{t}$ tabel $<\mathrm{t}$ hitung $<\mathrm{t}$ tabel, maka Ho diterima dan Ha ditolak

2) Menemukan nilai t hitung dengan rumus:

$$
\text { t hitung }=\frac{\text { Koefisien } \beta}{\text { Standareror }}
$$

3) Membuat kesimpulan dengan membandingkan hasil t hitung dengan t tabel.

\section{b. Uji F (Uji Simultan)}

Menurut Algifari (2015:80), pengujian ini dilakukan untuk mengetahui apakah semua variabel independen secara bersama-sama (simultan) dapat berpengaruh terhadap variabel dependen. Uji F dijelaskan dengan analisis varian (analysis of variance $=$ ANOVA).

Kriteria pengujiannya adalah sebagai berikut :

Apabila F tabel > F hitung, maka Ho diterima dan Ha ditolak.

Apabila F tabel < F hitung, maka Ho ditolak dan Ha diterima. 


\subsubsection{Koefisien Determinasi $\left(\mathbf{R}^{2}\right)$}

Koefisien determinasi $\left(\mathrm{R}^{2}\right)$ menunjukkan besarnya variasi nilai variabel dependen yang dapt dijelaskan oleh semua variable independen. Angka ini sering juga digunakan sebagi ukuran besarnya pengaruh (dalam persen) semua variabel independen secara bersama-sama terhadap nilai variabel dependen. Besarnya persentase pengaruh semua variabel independen terhadap nilai variabel dependen dapat diketahui dari besarnya koefisien determinasi $\left(\mathrm{R}^{2}\right)$ persamaan regresi estimasi. Besarnya koefisien determinasi dari 0 (nol) sampai dengan 1 (satu). Semakin mendekati nol besarnya koefisien determinasi suatu persamaan regresi estimasi menunjukkan bahwa semakin kecil pula pengaruh (kemampuan menjelaskan) semua variabel independen terhadap nilai variabel dependen. Sebaliknya, semakin mendekati satu besarnya koefisien determinasi suatu persamaan regresi estimasi menunjukkan semakin besar pula pengaruh (kemampuan menjelaskan) semua variabel independen terhadap variabel dependen (Algifari, 2015:75).

\section{Hasil dan pembahasan}

\subsection{Hasil Uji Validitas}

Tabel 1. Rekapitulasi Hasil Uji Validitas

\begin{tabular}{lllll}
\hline \multicolumn{1}{c}{ Variabel } & \multicolumn{1}{c}{ Indikator } & r hitung & Sig. & Keterangan \\
\hline \multirow{3}{*}{ Aspek fisik } & $\mathrm{X}_{1.1}$ & 0,947 & 0,000 & Valid \\
& $\mathrm{X}_{1.2}$ & 0,943 & 0,000 & Valid \\
& $\mathrm{X}_{1.3}$ & 0,902 & 0,000 & Valid \\
\hline \multirow{2}{*}{ Reliabilitas } & $\mathrm{X}_{2.1}$ & 0,948 & 0,000 & Valid \\
& $\mathrm{X}_{2.2}$ & 0,957 & 0,000 & Valid \\
\hline \multirow{4}{*}{ Interaksi Personal } & $\mathrm{X}_{3.1}$ & 0,865 & 0,000 & Valid \\
& $\mathrm{X}_{3.2}$ & 0,932 & 0,000 & Valid \\
& $\mathrm{X}_{3.3}$ & 0,918 & 0,000 & Valid \\
Pemecahan & $\mathrm{X}_{3.4}$ & 0,921 & 0,000 & Valid \\
Masalah & $\mathrm{X}_{4.1}$ & 0,979 & 0,000 & Valid \\
& $\mathrm{X}_{4.2}$ & 0,962 & 0,000 & Valid \\
\multirow{3}{*}{ Kebijakan } & $\mathrm{X}_{4.3}$ & 0,975 & 0,000 & Valid \\
& $\mathrm{X}_{5.1}$ & 0,948 & 0,000 & Valid \\
& $\mathrm{X}_{5.2}$ & 0,963 & 0,000 & Valid \\
& $\mathrm{X}_{5.3}$ & 0,829 & 0,000 & Valid \\
\hline
\end{tabular}




\begin{tabular}{lcccc}
\hline & $\mathrm{Y}_{1}$ & 0,862 & 0,000 & Valid \\
Keputusan & $\mathrm{Y}_{2}$ & 0,881 & 0,000 & Valid \\
pembelian & $\mathrm{Y}_{3}$ & 0,904 & 0,000 & Valid \\
& $\mathrm{Y}_{4}$ & 0,909 & 0,000 & Valid \\
& $\mathrm{Y}_{5}$ & 0,862 & 0,001 & Valid \\
\hline
\end{tabular}

Sumber: Data diolah, 2020

Berdasarkan Tabel 1 dapat diketahui bahwa masing-masing indikator yang digunakan baik dalam variabel independen (aspek fisik, reliabilitas, interaksi personal, pemecahan masalah, dan kebijakan) maupun variabel dependen (keputusan pembelian) mempunyai nilai signifikansi yang lebih kecil dari 0,05. Hal ini berarti indikator-indikator yang digunakan dalam variabel penelitian ini layak atau valid digunakan sebagai pengumpul data.

\subsection{Hasil Uji Reliabilitas}

Tabel 2. Hasil Uji Reliabilitas

\begin{tabular}{lll}
\hline Variabel & $\alpha$ & Keterangan \\
\hline Aspek fisik & 0,923 & \\
Reliabilitas & 0,895 & \\
Interaksi personal & 0,930 & Reliabel \\
Pemecahan Masalah & 0,970 & $\alpha>0,7$ \\
Kebijakan & 0,903 & \\
Keputusan pembelian & 0,929 & \\
\hline
\end{tabular}

Sumber: Data diolah, 2020

Berdasarkan Tabel 2 dapat disimpulkan bahwa semua variabel yang digunakan dalam penelitian ini adalah reliabel, karena memiliki nilai Cronbach Alpha $(\alpha)$ lebih besar dari 0,70 .

\subsection{Uji Asumsi Klasik}




\subsubsection{Uji Normalitas}
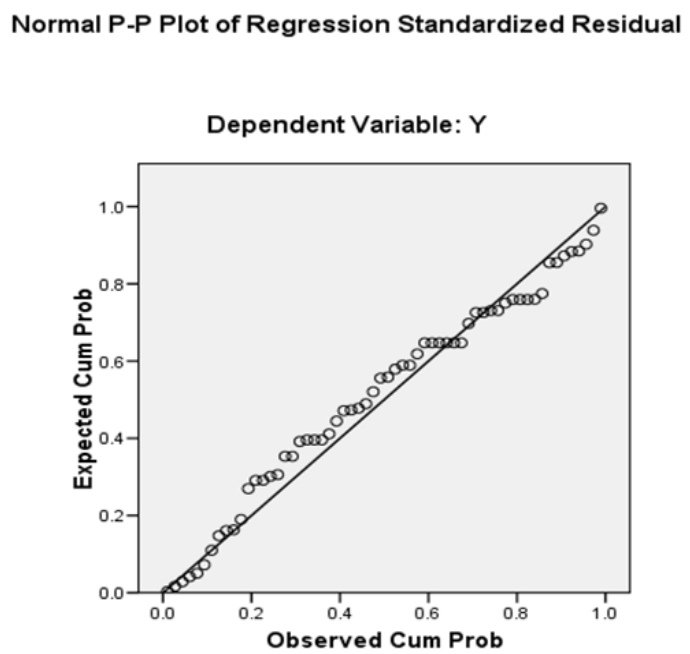

Gambar 2. Hasil uji Normalitas

Sumber: Data diolah, 2020

Berdasarkan Gambar 2 diketahui grafik hasil uji normalitas terhadap model regresi, terdapat titik-titik menyebar di sekitar garis diagonal, serta penyebarannya mengikuti arah garis diagonal. Maka model regresi layak dipakai karena telah memenuhi asumsi normalitas.

\subsubsection{Uji Multikoliniaritas}

Tabel 3. Hasil Uji Multikolinearitas

\begin{tabular}{lll}
\hline Variabel & VIF & Keterangan \\
\hline Aspek Fisik & 3,814 & \\
Reliabilitas & 4,126 & VIF $<10$ \\
Interaksi Personal & 5,447 & Tidak ada multikolinearitas \\
Pemecahan Masalah & 3,559 & \\
Kebijakan & 4,757 & \\
\hline
\end{tabular}

Sumber: Data diolah, 2020

Berdasarkan hasil analisis Collinearity Statistic diketahui bahwa dalam model tidak terjadi multikolinearitas, hal ini dapat dilihat pada Tabel 3 dimana nilai VIF dari masing-masing variabel kurang dari 10. 


\subsubsection{Uji Heteroskedastisitas}

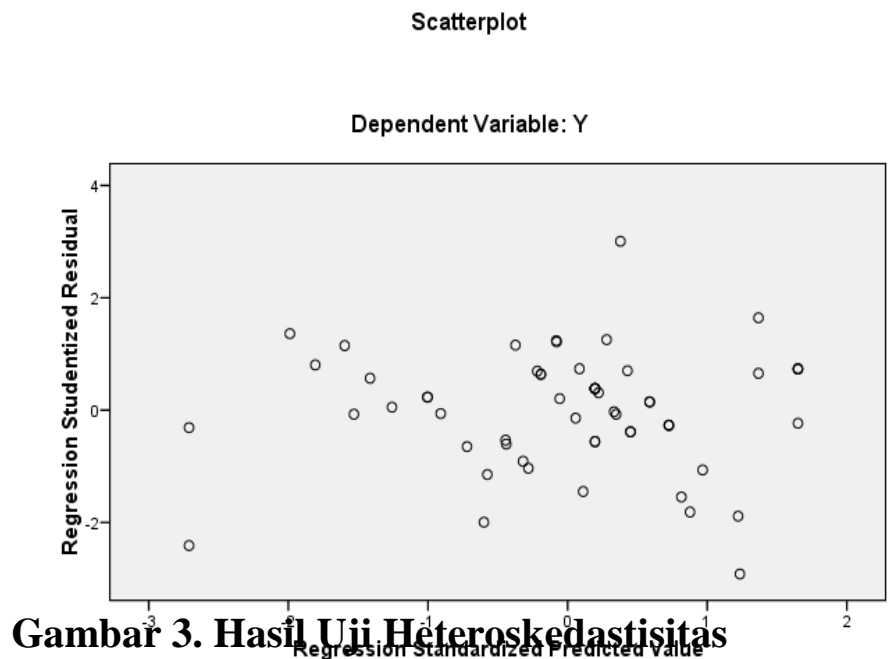

Sumber: Data diolah, 2020

Hasil analisis dari grafik scatterplots pada Gambar 3 terdapat titik-titik menyebar secara acak, tidak membentuk suatu pola tertentu yang jelas, serta tersebar baik di atas maupun di bawah angka 0 pada sumbu Y. Hal ini berarti tidak terjadi heteroskedastisitas pada model regresi.

\subsubsection{Analisis Regresi Linier Berganda}

Tabel 4. Hasil Perhitungan Regresi Linier Berganda

\begin{tabular}{lllll}
\hline Variabel & Koef. Regresi & thitung & Sig. & Keterangan \\
\hline Konstanta & 1,000 & 1,054 & 0,297 & - \\
$\mathrm{X}_{1}$ & 0,443 & 3,623 & 0,001 & Signifikan \\
$\mathrm{X}_{2}$ & 0,436 & 2,603 & 0,012 & Signifikan \\
$\mathrm{X}_{3}$ & 0,365 & 3,312 & 0,002 & Signifikan \\
$\mathrm{X}_{4}$ & 0,288 & 2,139 & 0,037 & Signifikan \\
$\mathrm{X}_{5}$ & 0,041 & 0,262 & 0,795 & Tidak Signifikan \\
\hline $\mathrm{R}$ & & & 0,952 \\
$\mathrm{R}$ Square & & & & 0,906 \\
$\mathrm{~F}$ hitung & & & & 103,869 \\
Sig & & & & 0,000 \\
$\mathrm{~N}$ & & & & 60 \\
\hline
\end{tabular}

Sumber: Data diolah, 2020

Berdasarkan hasil tersebut dapat diperoleh persamaan regresi linier berganda sebagai berikut: 


\section{$Y=1,000+0,443 X_{1}+0,436 X_{2}+0,365 X_{3}+0,288 X_{4}+0,041 X_{5}$}

\subsubsection{Pengujian Hipotesis}

\subsubsection{Pengujian Secara Parsial (Uji t)}

Berdasarkan tabel 4 tersebut dapat diketahui besarnya pengaruh masing-masing variabel bebas terhadap variabel terikat sebagai berikut:

1. Pengaruh variabel aspek fisik $\left(\mathrm{X}_{1}\right)$ terhadap keputusan pembelian $(\mathrm{Y})$

Berdasarkan Tabel 4 dapat diketahui bahwa thitung yaitu 3,623 dan signifikansi $<\alpha$ yaitu 0,001 . Karena thitung memiliki tingkat probabilitas yang lebih kecil dari 5\%, maka $\mathrm{H}_{0}$ ditolak, berarti secara parsial variabel aspek fisik $\left(\mathrm{X}_{1}\right)$ mempunyai pengaruh signifikan terhadap keputusan pembelian (Y). Sehingga, hipotesis yang menyatakan bahwa terdapat pengaruh Aspek fisik (physical aspect) terhadap keputusan pembelian di Toko Basmalah Kasiyan terbukti kebenarannya atau $\mathrm{H}_{1}$ diterima.

2. Pengaruh variabel reliabilitas $\left(\mathrm{X}_{2}\right)$ terhadap keputusan pembelian $(\mathrm{Y})$

Berdasarkan Tabel 4 dapat diketahui bahwa thitung yaitu 2,603 dan signifikansi $<\alpha$ yaitu 0,012 . Karena $t_{\text {hitung }}$ memiliki tingkat probabilitas yang lebih kecil dari 5\%, maka $\mathrm{H}_{0}$ ditolak, berarti secara parsial variabel reliabilitas $\left(\mathrm{X}_{2}\right)$ mempunyai pengaruh signifikan terhadap keputusan pembelian (Y). Sehingga, hipotesis yang menyatakan bahwa terdapat pengaruh reliabilitas (reliability) terhadap keputusan pembelian di Toko Basmalah Kasiyan terbukti kebenarannya atau $\mathrm{H}_{2}$ diterima.

3. Pengaruh variabel interaksi personal $\left(\mathrm{X}_{3}\right)$ terhadap keputusan pembelian $(\mathrm{Y})$ Berdasarkan Tabel 4dapat diketahui bahwa thitung yaitu 3,312 dan signifikansi $<\alpha$ yaitu 0,002. Karena thitung memiliki tingkat probabilitas yang lebih kecil dari 5\%, maka $\mathrm{H}_{0}$ ditolak, berarti secara parsial variabel interaksi personal $\left(\mathrm{X}_{3}\right)$ mempunyai pengaruh signifikan terhadap keputusan pembelian (Y). Sehingga, hipotesis yang menyatakan bahwa terdapat pengaruh interaksi personal (personal interaction) terhadap keputusan pembelian di Toko Basmalah Kasiyan terbukti kebenarannya atau $\mathrm{H}_{3}$ diterima.

4. Pengaruh variabel pemecahan masalah $\left(\mathrm{X}_{4}\right)$ terhadap keputusan pembelian $(\mathrm{Y})$ Berdasarkan Tabel 4 dapat diketahui bahwa thitung yaitu 2,139 dan signifikansi $<\alpha$ yaitu 0,037 . Karena thitung memiliki tingkat probabilitas yang lebih kecil dari 5\%, 
maka $\mathrm{H}_{0}$ ditolak, berarti secara parsial variabel pemecahan masalah $\left(\mathrm{X}_{4}\right)$ mempunyai pengaruh signifikan terhadap keputusan pembelian (Y). Sehingga, hipotesis yang menyatakan bahwa terdapat pengaruh pemecahan masalah (problem solving) terhadap keputusan pembelian di Toko Basmalah Kasiyan terbukti kebenarannya atau $\mathrm{H}_{4}$ diterima.

5. Pengaruh variabel kebijakan $\left(\mathrm{X}_{5}\right)$ terhadap keputusan pembelian $(\mathrm{Y})$

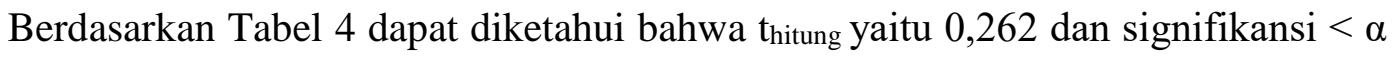

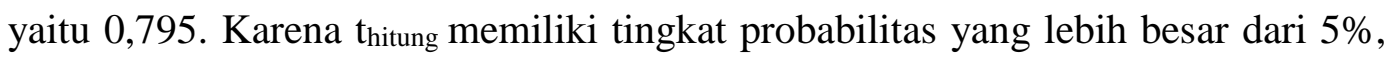
maka $\mathrm{H}_{0}$ diterima, berarti secara parsial kebijakan $\left(\mathrm{X}_{5}\right)$ tidak mempunyai pengaruh signifikan terhadap keputusan pembelian (Y). Sehingga, hipotesis yang menyatakan bahwa terdapat pengaruh kebijakan (policy) terhadap keputusan pembelian di Toko Basmalah Kasiyan tidak terbukti kebenarannya atau $\mathrm{H}_{5}$ ditolak.

\subsubsection{Pengujian Secara Simultan (Uji F)}

Berdasarkan Tabel 4 dapat dilihat bahwa nilai F hitung sebesar 103,869 dan nilai probabilitas $(P$ value $)<0,05$ atau $(0,000<0,05)$ maka dapat dinyatakan bahwa aspek fisik, reliabilitas, interaksi personal, pemecahan masalah, dan kebijakan terbukti berpengaruh secara bersama-sama dan signifikan terhadap keputusan pembelian. Sehingga, hipotesis yang menyatakan bahwa terdapat pengaruh secara simultan aspek fisik (physical aspect), reliabilitas (reliability), interaksi personal (personal interaction), pemecahan masalah (problem solving), kebijakan (policy) terhadap keputusan pembelian di Toko Basmalah Kasiyan terbukti kebenarannya atau $\mathrm{H}_{6}$ diterima.

\subsubsection{Koefisien Determinasi Berganda $\left(R^{2}\right)$}

Berdasarkan hasil analisis yang bisa dilihat pada 4 diperoleh hasil koefisien determinasi berganda $\left(\mathrm{R}^{2}\right)$ sebesar 0,906 , hal ini berarti $90,6 \%$ perubahan keputusan pembelian dipengaruhi oleh variabel aspek fisik, reliabilitas, interaksi personal, pemecahan masalah, dan kebijakan sedangkan sisanya sebesar 61,9\% disebabkan oleh faktor lain harga, promosi, distribusi, dan lain-lain yang tidak termasuk dalam persamaan regresi yang dibuat.

\subsection{Pembahasan}




\subsubsection{Pengaruh Aspek Fisik (physical aspect) terhadap Keputusan}

\section{Pembelian}

Hasil uji regresi menunjukkan variabel aspek fisik berpengaruh positif dan signifikan terhadap keputusan pembelian dengan koefisien 0,443. Hal ini berarti faktor aspek fisik yang diukur melalui tata letak rak di Toko Basmalah memudahkan pembeli untuk bergerak di dalam toko, tata letak barang di Toko Basmalah rapi dan memudahkan pembeli untuk mencarinya, dan ruangan di Toko Basmalah bersih merupakan suatu faktor yang menentukan keputusan pembelian di Toko Basmalah Kasiyan. Hasil penelitian ini mendukung teori kualitas layanan ritel yaitu terkait aspek fisik (physical aspects), meliputi penampilan fisik dan kenyamanan yang di tawarkan kepada pelanggan berkaitan dengan layout fasilitas fisik (misalnya, memudahkan pelanggan untuk bergerak di dalam toko dan mencari barang yang dibutuhkan). Aspek fisik yang ada di toko basmalah sudah baik dan mampu mempengaruhi keputusan pembelian konsumen. Hasil penelitian ini sejalan dengan penelitian yang dilakukan oleh Nova dan Parjono (2017) tentang pengaruh suasana toko dan kualitas layanan terhadap keputusan pembelian konsumen pada Toserba Gajah Mada di Jombang. Hasil penelitian menunjukkan bahwa suasana toko secara parsial berpengaruh positif terhadap keputusan pembelian dan kualitas layanan secara parsial berpengaruh positif terhadap keputusan pembelian.

\subsubsection{Pengaruh Reliabilitas (Reliability) terhadap Keputusan Pembelian}

Hasil uji regresi menunjukkan variabel reliabilitas berpengaruh positif dan signifikan terhadap keputusan pembelian dengan koefisien 0,436. Hal ini berarti faktor reliabilitas yang diukur melalui Toko Basmalah menjual produk yang berkualitas sesuai yang dijanjikan dan Toko Basmalah memberikan kualitas layanan yang tepat dan cepat merupakan suatu faktor yang menentukan keputusan pembelian di Toko Basmalah Kasiyan. Hasil penelitian ini mendukung teori kualitas layanan ritel yaitu tentang reliabilitas (reliability), yang pada prinsipnya sama dengan dimensi reliabilitas pada model SERVQUAL, hanya saja di sini reliabilitas dipilah ke dalam 2 sub-dimensi, yaitu memenuhi janji (keeping promises) dan memberikan layanan dengan tepat (doing it right). Hasil penelitian ini juga mendukung penelitian terdahulu yang dilakukan oleh Fiki (2018) yang 
berjudul pengaruh kualitas layanan dan suasana toko terhadap keputusan pembelian pada toko alfamart Ketintang Surabaya. Hasil observasi variabel kualitas layanan pada toko Alfamart Ketintang Surabaya memiliki indikator berwujud, kehandalan, daya tanggap, jaminan dan empati yang diperhatikan untuk menunjang kenyamanan pelanggan.

\subsubsection{Pengaruh Interaksi Personal (personal interaction) terhadap \\ Keputusan Pembelian}

Hasil uji regresi menunjukkan variabel interaksi personal berpengaruh positif dan signifikan terhadap keputusan pembelian dengan koefisien 0,365. Hal ini berarti faktor interaksi personal yang diukur melalui karyawan di Toko Basmalah ramah dan sopan, karyawan di Toko Basmalah melayani pembeli dengan cepat, karyawan di Toko Basmalah suka membantu pembeli jika ada kesulitan dalam mencari barang yang akan dibeli, dan karyawan di Toko Basmalah memberikan perhatian individual kepada para pembeli merupakan suatu faktor yang menentukan keputusan pembelian di Toko Basmalah Kasiyan. Hasil penelitian ini mendukung teori kualitas layanan ritel yaitu interaksi personal (personal interaction), mengacu pada kemampuan karyawan jasa dalam menumbuhkan kepercayaan pelanggan dan sikap sopan/suka membantu. Pada prinsipnya, dimensi ini berkaitan dengan cara karyawan memperlakukan para pelanggan. Sebagai perusahaan yang fokus dengan pelanggannya, maka dituntut mampu memberikan perhatian secara personal dengan baik. Hal ini juga diberikan oleh toko basmalah kasiyan, yaitu memberikan pelayanan berupa interaksi personal yang tinggi kepada para pelanggannya, misalnya saja karyawan selalu membantu pelanggannya yang membutuhkan. Hasil penelitian ini tidak mendukung penelitian yang dilakukan oleh Fiki (2018) yang berjudul pengaruh kualitas layanan dan suasana toko terhadap keputusan pembelian pada toko alfamart Ketintang Surabaya. Kualitas layanan yang terdiri dari indikator berwujud, kehandalan, daya tanggap, jaminan dan empati secara parsial tidak berpengaruh terhadap keputusan pembelian. 


\subsubsection{Pengaruh Pemecahan Masalah (problem solving) terhadap Keputusan}

\section{Pembelian}

Hasil uji regresi menunjukkan variabel pemecahan masalah berpengaruh positif dan signifikan terhadap keputusan pembelian dengan koefisien 0,288. Hal ini berarti faktor pemecahan masalah yang diukur melalui Toko Basmalah memberikan kemudahan kepada pembeli jika ada komplain, Toko Basmalah menerima penukaran atau retur jika produk yang dibeli rusak, dan Toko Basmalah memberikan solusi yang tepat jika ada keluhan konsumen merupakan suatu faktor yang menentukan keputusan pembelian di Toko Basmalah Kasiyan. Hasil penelitian ini mendukung teori tentang SERVQUAL yaitu ketanggapan (responsiveness), yaitu suatu kebijakan untuk membantu dan memberikan pelayanan yang cepat (responsif) dan tepat kepada pelanggan, dengan penyampaian informasi yang jelas. Membiarkan pelanggan pelanggan menunggu menciptakan persepsi yang negatif dalam kualitas pelayanan (Parasuramant dkk., 1998). Selain teori tersebut, penelitian ini juga mendukung teori kualitas layanan ritel terkait pemecahan masalah (problem solving), berkaitan dengan penanganan retur, penukaran, dan komplain. Hasil penelitian ini juga mendukung penelitian yang dilakukan oleh Fadhilatul dan Sasi (2016) dengan judul pengaruh produk, kualitas produk, dan kualitas layanan terhadap keputusan pembelian. Suatu kualitas atau mutu dikatakan sangat baik jika penyedia jasa memberikan layanan yang melebihi harapan para pelanggan. Mutu atau kualitas dikatakan baik jika penyedia jasa memberikan layanan yang setara dengan yang diharapkan oleh pelanggan. Hal ini akan mendorong konsumen untuk melakukan pembelian.

\subsubsection{Pengaruh Kebijakan (policy) terhadap Keputusan Pembelian}

Hasil uji regresi menunjukkan variabel kebijakan berpengaruh positif namun tidak signifikan terhadap keputusan pembelian dengan koefisien 0,041. Hal ini berarti faktor kebijakan yang diukur melalui jam operasi Toko Basmalah yang di mulai pukul 07.00-22.00 memudahkan pembeli dalam berbelanja, Toko Basmalah menyediakan tempat parkir yang luas sangat dan nyaman, serta Toko Basmalah memberikan kemudahan kepada pembeli dalam bentuk layanan tambahan seperti pembayaran non tunai dengan kartu kredit bukan merupakan 
suatu faktor yang menentukan keputusan pembelian di Toko Basmalah Kasiyan. Hal tersebut karena kebijakan yang diberikan oleh toko basmalah kasiyan sudah sama dengan kebijakan yang dilakukan oleh ritel modern yang lain yang ada disekitar toko basmalah seperti alfamart dan indomart, sehingga konsumen sudah merasa biasa dengan layanan tersebut.

Hasil penelitian ini tidak mendukung penelitian yang dilakukan oleh Mimi dan Feliciana (2017) yang berjudul pengaruh harga, pelayanan, lokasi, dan keragaman produk terhadap keputusan pembelian pada Hypermart Puri Indah di Jakarta Barat. Dalam bisnis, mencari dan menentukan lokasi merupakan tugas yang paling penting karena penentuan lokasi yang tepat merupakan kunci kesuksesan suatu bisnis. Faktor yang harus dipertimbangkan dalam menentuan lokasi, yaitu kestrategisan, apakah daerah tersebut dapat dijadikan pusat bisnis dan arus lalu lintas. Arus lalu lintas mempengaruhi penempatan lokasi usaha karena dapat menarik konsumen untuk mengunjungi bisnis tersebut dan bahkan juga memungkinkan konsumen untuk membeli (Utami, 2012:89). Konsumen cenderung memilih bisnis yang yang berlokasi di tempat yang mudah dijangkau, aman dan nyaman, dan memiliki area parkir yang luas. Lokasi yang strategis dapat mempengaruhi keputusan pembelian konsumen.

Hasil penelitian ini juga tidak mendukung penelitian Tengku dkk (2020) dengan judul penelitian Persepsi Konsumen, Kualitas Layanan Dan Minat Beli Pada Ritel Tradisional Dan Modern. Penelitian ini bertujuan untuk mengetahui pengaruh persepsi konsumen terhadap minat beli, untuk mengetahui pengaruh kualitas layanan terhadap minat beli dan untuk mengetahui pengaruh persepsi konsumen dan kualitas layanan secara simultan terhadap minat beli pada ritel tradisional dan modern di Kecamatan Langsa Baro. Hasil penelitian menunjukkan bahwa persepsi konsumen berpengaruh tidak signifikan terhadap minat beli, kualitas layanan berpengaruh signifikan terhadap minat beli. Secara simultan persepsi konsumen dan kualitas layanan berpengaruh signifikan terhadap minat beli pada ritel tradisional dan modern di Kecamatan Langsa Baro. 


\subsubsection{Pengaruh aspek fisik (physical aspect), reliabilitas (reliability), interaksi personal (personal interaction), pemecahan masalah (problem solving), kebijakan (policy) terhadap keputusan pembelian di Toko Basmalah Kasiyan}

Hasil penelitian menunjukkan bahwa aspek fisik (physical aspect), reliabilitas (reliability), interaksi personal (personal interaction), pemecahan masalah (problem solving), kebijakan (policy) berpengaruh secara simultan terhadap keputusan pembelian di Toko Basmalah Kasiyan. Berdasarkan hasil tersebut maka secara bersama-sama variabel kualitas layanan ritel berpengaruh terhadap keputusan pembelian di toko basmalah kasiyan. Berdasarkan uji simultan diperoleh hasil hasil koefisien determinasi berganda $\left(\mathrm{R}^{2}\right)$ sebesar 0,906 , hal ini berarti 90,6\% perubahan keputusan pembelian dipengaruhi oleh variabel aspek fisik, reliabilitas, interaksi personal, pemecahan masalah, dan kebijakan sedangkan sisanya sebesar $61,9 \%$ disebabkan oleh faktor lain harga, promosi, distribusi, dan lain-lain yang tidak termasuk dalam persamaan regresi yang dibuat. Hasil penelitian ini mendukung penelitian yang dilakukan oleh Fadhilatul dan Sasi (2016), Farida dan Apriatni (2016), Nova dan Parjono (2017), dan Fiki (2018) dengan hasil penelitian menunjukkan bahwa kualitas layanan ritel berpengaruh secara simultan terhadap keputusan pembelian.

\section{Kesimpulan}

Hasil penelitian ini diperoleh kesimpulan antara lain:

1. Terdapat pengaruh secara parsial aspek fisik (physical aspect), reliabilitas (reliability), interaksi personal (personal interaction), pemecahan masalah (problem solving) terhadap keputusan pembelian di Toko Basmalah Kasiyan.

2. Tidak terdapat pengaruh kebijakan (policy) terhadap keputusan pembelian di Toko Basmalah Kasiyan.

3. Terdapat pengaruh secara simultan aspek fisik (physical aspect), reliabilitas (reliability), interaksi personal (personal interaction), pemecahan masalah (problem solving) terhadap keputusan pembelian di Toko Basmalah Kasiyan. 


\section{Daftar Pustaka}

Algifari. 2015. Analisis Regresi untuk Bisnis dan Ekonomi. Yogyakarta: BPFE.

Dabholkar, P. A., Thorpe, D. I., \& Rentz, J. O. (1996). A measure of service quality for retail stores: scale development and validation. Journal of the Academy of marketing Science, 24(1), 3.

Fadhilatul \& Sasi (2016). Pengaruh Harga, Kualitas Produk Dan Kualitas Layanan Terhadap Keputusan Pembelian. Jurnal Ilmu dan Riset Manajemen : Volume 5, Nomor 7 .

Fiki. 2018. Pengaruh Kualitas Layanan dan Suasana TokomTerhadap Keputusan Pembelian Pada Toko Alfamart Ketintang Surabaya. Jurnal Pendidikan Tata Niaga (JPTN). ISSN: 2337-6708, Volume 06, Nomor 03.

Kotler, F., \& Keller, K. (2008). Marketing-Menedzhment [MarketingManagement]. Saint-Petersburg: Piter.

Kotler, P., \& Armstrong, G. (2010). Principles of marketing. Pearson education.

Mimi \& Feliciana (2017). Pengaruh Harga, Pelayanan, Lokasi, Dan Keragaman Produk Terhadap Keputusan Pembelian Pada Hypermart Puri Indah Di Jakarta Barat. Jurnal Ekonomi/Volume XXII, No. 01, Maret 2017: 124-131. Nova \& Parjono (2017). Pengaruh Suasana Toko Dan Kualitas Layanan Terhadap Keputusan Pembelian Konsumen Pada Toserba Gajah Mada Di Jombang. Jurnal Pendidikan Tata Niaga (JPTN) ISSN: 2337-6708 Volume 01 Nomor 01.

Parasuraman, A., Zeithaml, V. A., \& Berry, L. L. (1988). Servqual: A multiple-item scale for measuring consumer perc. Journal of retailing, 64(1), 12.

Riduwan, Drs. 2008. Cara Menggunakan dan Memakai Analisis Jalur (path analysis). Bandung : Alfabeta.

Siregar, Ir. Sofyan. 2015. Statistik Parametrik untuk Penelitian Kuantitatif. Jakarta: Bumi Aksara.

Sugiyono. 2009. Metode Penelitian Bisnis. CV. Alfabeta. Bandung. Tengku, dkk (2020). Persepsi Konsumen, Kualitas Layanan Dan Minat Beli Pada Ritel Tradisional Dan Modern. Jurnal Manajemen Motivasi 16 (2020) 29-37. 
Tjiptono, Fandy, 2001, Manajemen Jasa. Yogyakarta: Penerbit ANDI.

---------, Fandy, 2007, Manajemen Jasa. Yogyakarta: Penerbit ANDI.

Utami, Chirstina Whidya. 2012. Manajemen Ritel: Strategi dan Implementasi Operasional Bisnis Ritel Modern di Indonesia Edisi 2. Jakarta. Salemba Empat

Widarjono, A. (2015). Analisis multivariat terapan dengan program SPSS, AMOS, dan SMARTPLS. Yogyakarta: UPP STIM YKPN.

(https://www.kaskus.co.id/thread/5dafe86ec8393a188845363d/toko-basmalahpenantang-baru-supermarket-di-indonesia/) 